\title{
Anti-GD2 Monoclonal Antibody
}

National Cancer Institute

\section{Source}

National Cancer Institute. Anti-GD2 Monoclonal Antibody. NCI Thesaurus. Code C155653.

Any monoclonal antibody that is directed against the GD2 (GD-2) antigen. 